\title{
Budaya Dalam Peningkatan Patient Safety di Lingkup Kerja
}

\author{
Queen Agave (queenasiregar@gmail.com)
}

\section{Latar Belakang}

Schein (1992) mendefinisikan
budaya kerja sebagai kebiasaan
orang bekerja bekerja dalam suatu
kelompok, kelompok, nilai, filosofi filosofi
dan aturan-aturan aturan-aturan dalam
kelompok kelompok yang membuat mereka
bisa bekerjasama. Karakteristiknya antara
lain: budaya kerja sebagai suatu pola yang
dibentuk berdasarkan asumsi-asumsi dasar;
dibentuk oleh kelompok sebagai upaya
untuk mengatasi masalah-masalah yang muncul dalam lingkungan kerja dan untuk beradaptasi dengan lingkungan eksternal mencerminkan tradisi yang dianggap berjalan dengan baik, diajarkan kepada anggota-anggota baru dalam organisasi, dianggap sebagai cara terbaik untuk berfikir, berperilaku dan berfikir.Secara singkat budaya kerja adalah bagaimana bagaimana kita menyelesaikan menyelesaikan pekerjaan pekerjaan ditempat ditempat kerja. Budaya kerja berperan berperan penting dalam penting dalam keberhasilan keberhasilan atau kegagalan kegagalan suatu organisasi organisasi pelayanan pelayanan kesehatan kesehatan dan juga dalam konteks patient safety.

Hampir setiap tindakan medic menyimpan potensi resiko. Banyaknya jenis obat, jenis pemeriksaan dan prosedur, serta jumlah pasien dan staff Rumah Sakit yang cukup besar, merupakan hal yang potensial bagi terjadinya kesalahan medis (medical errors). Menurut Institute of Medicine (1999). Kesalahan yang terjadi dalam proses asuhan medis ini akan mengakibatkan atau berpotensi mengakibatkan cedera pada pasien, bisa berupa Near Miss atau Adverse Event (Kejadian Tidak Diharapkan/KTD). Near Miss atau Nyaris Cedera (NC) merupakan suatu kejadian akibat melaksanakan suatu tindakan (commission) atau tidak mengambil tindakan yang seharusnya diambil (omission), yang dapat mencederai pasien, tetapi cidera serius tidak terjadi, karena keberuntungan (misalnya,pasien terima suatu obat kontra indikasi tetapi tidak timbul reaksi obat), pencegahan (suatu obat dengan overdosis lethal akan diberikan. 


\section{Metode}

Metode ini menggunakan metode kualitatif analisis berlandaskan teori dari buku, jurnal, e-book ataupun sumber informasi lainnya yang memuat informasi dengan Budaya Dalam Peningkatan Patient Safety di Lingkup Kerja. Dengan metode ini informasi pembahasan mengenai budaya

\section{Hasil}

Berdasarkan metode kualitatif analisis, saya mendapatkan hasil dari budaya dalam peningkatan patient safety di lingkup kerja. Fungsi dan efek dari budaya kerja antara lain; Menetapkan batas-batas b. Membentuk identitas c. Membentuk komitment untuk mencapai tujuan organisasi yang lebih tinggi d. Mengembangkan stabilitas sistem sosial e. Sebagai mekanisme regulasi terhadap perilaku dan sikap f. Efek:Mmenurunkan kecemasan yang muncul akibat ketidakmampuan untuk mengerti, memprediksi dan mengontrol kejadian. g. Memiliki potensi untuk meningkatkan performa, kepuasan, ekspektasi, sikap h. dan perilaku dalam organisasi i. Mempengaruhi kesehatan (wellbeings) pekerja j. Jika tidak keselamatan pasien bagi seorang perawat dapat memahami dan mempelajari tentang Budaya Keselamatan Keselamatan Dalam Berorganisasi Berorganisasi, patient safety, pergeseran pradigma dalam patient safety, strategi penerapan budaya patient safety, Maturitas budaya patient safety, dll.

disesuaikan dengan perubahan harapan stakeholders internal dan internal dan eksternal, efektifitasnya eksternal, efektifitasnya bisa menurun.

Budaya kerja ini berada dalam tiga level, level inti, strategis, dan manifestasi. Ditingkat inti, budaya kerja ini dipegang kuat dan seringkali berupa ideologi, nilai, dan asumsi yang tidak tertulis. Di tingkat strategis, nilai-nilai dan pemahaman pemahaman yang ada dalam organisasi organisasi diekspresik diekspresik an untuk mencerminkan mencerminkan budaya yang budaya yang diharapkan diharapkan organisasi organisasi itu. Di tingkat tingkat manifestasi, manifestasi, budaya organisasi budaya 
organisasi ditunjukkan dalam perilaku dan kondisi organisasi sehari-haro yang seringkali merupakan kompromi antara budaya organisasi ditingkat inti dan strategis, dan mencerminkan situasi terkini. Berdasarkan tipenya, budaya kerja dibedakan menjadi 3, yaitu budaya yangkonstruktif, pasif-defensif, dan agresifdefensif. Budaya yang konstruktif mengutamakan interaksi antar individu dalam organisasi, saling membantu, memiliki norma afiliasi, bisa mencapai tujuannya atau memenuhi kebutuhan organisasi, bisa mengaktualisasi diri, humanistik, dan saling mendorong untuk menjadi lebih baik. Individu dalam lingkungan

organisasi yang berbudaya berbudaya pasifdefensif pasifdefensif akanaling akanaling berinteraksi berinteraksi dengan cara yang tidak mengancam dirinya sendiri.

\section{Pembahasan}

\section{Budaya Keselamatan Dalam} Berorganisasi

Berbagai penelitian pada berbagai industri yang membutuhkan ketepatan tinggi(high reliability organization), seperti industri pesawat terbang, atau instalasi pembangkit tenaga nuklir pembangkit tenaga nuklir menunjukkan bahwa safety menunjukkan bahwa safety culture merupakan culture merupakan prioritas prioritas pertama pertama dalam industri industri tersebut. tersebut. Industri-industri Industriindustri semacam semacam ini mempunyai mempunyai beberapa karakteristik:

a. Mempunyai otonomi yang tinggi, tetapi tetap ada saling ketergantungan. Setiap individu dalam organisasi mempunyai otonomi sebagai pekerja yang independen, tetapi tetap membutuhkan pekerja yang lain untuk menyelesaikan pekerjaan nya.

b. Mempunyai beberapa tim dengan budaya kerja yang berbeda-beda yang juga 
saling membutuhkan.

Misalnya seorang dokter

merupakan bagian dari

tim dokter dan seorang

perawat

merupakan bagian bagia

n dari tim perawat.

perawat. Tetapi dokter

membutuhkan

membutuhkan perawat

perawat dalam

prakteknya dan demikian

pula sebaliknya.

c. Selalu waspada terhadap

semua resiko yang

mengancam keselamatan

(safety).

Untuk

menciptakan budaya ini

biasanya organisasi sudah

mempunyai aturan-aturan

dan prosedur formal,

tetapi yang lebih penting

adalah adanya perhatian

khusus terhadap situasi-

situasi yang beresiko

tinggi dan tidak hanya

sekedar mematuhi aturan

dan prosedur secara

mematuhi aturan dan

prosedur secara rutin.

Untuk it rutin. Untuk itu, biasanya ada $\mathrm{u}$, biasanya ada satu petugas yang secara rutin mensupervisi dan memonitor respon terhadap situasi yang beresiko

d. Training mendapatkan prioritas yang tinggi. Kompetensi staf secara rutin dievaluasi , seringkali dengan melakukan simulasisimulasi.

e. Untuk situasi beresiko tinggi digunakan pendekatan kolaborasi. Pada situasi yang beresiko tinggi, garis hirarki formal ditinggalkan dahulu, semua anggota tim meningkatkan

kewaspadaan, dan masing-masing anggota tim ikut memonitor perkembangan situasi dan aktifitas anggota tim yang lain. Umpan balik terhadap performa perfo rma setiap anggota anggota timdiberikan 
timdiberikan secara langsung langsung dan bebas. Tujuan utamanya adalah keselamatan.

\section{Budaya Patient Safety}

Pentingnya mengembangkan budaya patient safety juga ditekankan dalam salahvsatu laporan Institute of Medicine "To Err Is Human” yang menyebutkan bahwavorganisasi bah wavorganisasi pelayanan pelayanan kesehatan kesehatan harus mengembangkan mengembangkan budaya keselamatanvsedemikian sehingga organisasi tersebut berfokus pada peningkatan reliabilitasvdan keselamatan pelayanan pasien". Hal ini ditekankan lagi oleh Nieva dan Sorra dalam penelitiannya penelitiannya yang menyebutkan menyebutkan bahwa budaya keselamatan yang buruk merupakan faktor resiko penting yang bisa mengancam keselamatan pasien.

Vincent (2005) dalam bukunya bahkan menyebutkan bahwa ancamanterhadap keselamatan pasien tersebut tidak dapat diubah, budaya patientsafety patientsafety dalam organisasi organisasi tidak diubah. tidak diubah. Budaya patient Budaya patient safety adalah produk dari nilai, sikap, kompetensi, dan pola perilaku individu dan kelompok yang menentukan komitmen, style dan kemampuan suatu organisasi pelayanan kesehatan terhadap program patient safety. Jika suatu organisasi pelayanan kesehatan tidak mempunyai budaya patient safety maka kecelakaan bisa terjadi akibat dari kesalahan laten,gangguan psikologis dan physiologis pada staf, penurunan penurunan produktifitas, produktifitas, berkurangnya berkurangnya kepuasan kepuasan pasien, pasien, dan bisa menimbulkan menimbulkan konflik interpersonal.

\section{Pergeseran paradigma dalam patient safety}

Karakteristik dari positive safety culture

a. Komunikasi dibentuk dari keterbukaan dan saling percaya

b. Alur informasi dan prosesing yang baik

c. Persepsi yang sama terhadap pentingnya keselamatan 
d. Disadari bahwa kesalahan tidak bisa sepenuhnya dihindari

e. Identifikasi ancaman laten terhadap keselamatan secara proaktif

f. Pembelajaran organisasi

g. Memiliki pemimpin yang komit dan eksekutif yang bertanggung jawab.

h. Pendekatan untuk tidak menyalahkan dan tidak memberikan hukuman

i. pada insiden yang dilaporkan.

\section{Tiga strategi penerapan budaya} patient safety:

a. Strategy Strategy 1

- Lakukan safe practices

- Rancang sistem pekerjaan yang memudahkan orang lain untuk melakukan tindakan medik secara benar

- Mengurangi ketergantungan pada ingatan

b. Edukasi Edukasi

- Kenali dampak akibat kelelahan dan kinerja

- Pendidikan dan pelatihan patient safety

- Melatih kerjasama antar

c. Akuntabilitas

- Melaporkan kejadian error
- Meminta maaf

- Melakukan remedial care

- Melakukan root cause analysis

\section{Mengukur Maturitas Budaya Patient Safety}

$\begin{array}{cr} & \text { Maturitas budaya patient } \\ \text { safety } & \text { dalam }\end{array}$
diklasifikasikan oleh Ashcroft et.al. (2005) menjadi lima tingkat maturitas: patologis, reaktif, kalkulatif, proaktif dan generatif. Di tingkat patologis, organisasi melihat keselamatan pasien melihat keselamatan pasien sebagai masalah, akibatnya informasi-iinformasi terkait patient safety akanditekan dan lebih berfokus pada menyalahkan individu demi menunjukkan kekuasaan pihak tertentu. pihak tertentu. Di tingkat reaktif, ngkat reaktif, organisasi sudah organisasi sudah menyadari bahwa menyadari bahwa keselamatan keselamatan pasien pasien adalah hal penting, penting, tetapi hanya berespon berespon ketika terjadi terjadi insiden insiden yang signifikan. Di tingkat kalkulatif, organisasi cenderung berpaku pada aturah-aturan dan jabatan dan kewenangan dalam organisasi. 
Setelah insiden terjadi, informasi tidak diteruskan atau bahkan diabaikan, kesalahan segera dibenarkan atau dijelaskan penyebabnya, tanpa analisis yang lebih mendalam lagi

\section{Level kematangan budaya patient safety}

Patologis Tidak ada sistem untuk pengembangan budaya patient safety Reaktif Sistemnya masih terpecah-pecah, dikembangkan sebagai bagian dari regulasi atau permintaan akreditasi atau untuk merespon insiden yang terjadi. Kalkulatif Terdapat pendekatan sistematis terhadap patient safety, tetapi implementasinya masih terkotak-kotak, dan analisis terhadap insiden masih terbatas pada situasi ketika insiden terjadi. Proaktif Terdapat pendekatan komprehensif terhadap budaya patient safety, intervensi yang evidence-based sudah diimplementasikan.Generative Pembentukan dan maintenance budaya patient patient safety adalah bagian sentral sentral dari misi organisasi, organisasi, efektifitas efektifitas intervensi intervensi selalu dievaluasi, selalu belajar daripengalaman yang salah maupun yang berhasil, danmengambil tindakan-tindakan yang berarti untukmemperbaiki situasi.

\section{Menilai Budaya Patient Safety}

Saat ini, budaya patient safety biasanya dinilai dengan selfcompletion questionnaires. Biasanya dilakukan dengan cara mengirimkan kuesioner kepada semua staff, untuk kemudian dihitung nilai rata-rata respon terhadap masingmasing item atau faktor. Langkah pertama dalam proses pengembangan budaya patient budaya patient safety adalah dengan adalah dengan menilai menilai budaya yang budaya yang ada. Tidak ada. Tidak banyak alat banyak alat yang tersedia untuk menilai budaya patient safety, salah satunya adalah 'Manchester Patient Safety Framework' . Biasanya ada jenis pernyataan yang digunakan untuk menilai dimensi budaya patient safety, pertama adalah pernyataanpernyataan pernyataan-pernyataan untuk mengukur mengukur nilai, pemahaman pemahaman dan sikap dan kedua adalah pernyataanpernyataan untuk mengukur aktifitas 
atau

perilaku

yang bertujuan bertujuan untuk

pengembangan pengembangan

budaya patient patient safety, safety, seperti seperti kepemimpinan, kepemimpinan, kebijakan dan prosedur.

\section{Penutup}

Salah satu tantangan dalam pengembangan patient safety adalah bagaimana bagaimana mengubah mengubah budaya yang ada menuju budaya patient patient safety. safety. Langkah Langkah penting penting pertama pertama adalah dengan menempatkan menempatkan patient patient safety sebagai sebagai salah satu prioritas prioritas utama dalam organisasi organisasi pelayanan pelayanan kesehatan, kesehatan, yang didukung didukung oleh eksekutif, timklinik, dan staf di semua level organisasi dengan pertanggung jawaban jawaban yang jelas. Beberapa Beberapa contoh langkahlangkah langkah-langkah lainnya lainnya disajikan disajikan dalam Perubahan budaya sangat terkait dengan pendapat dan perasaan individuindividu dalam organisasi.
Kesempatan untuk mengutarakan opini secara terbuka, dan keterbukaan ini harus diakomodasi oleh sistem sehingga memungkinkan semua individu untuk melaporkan dan mendiskusikan terjadinya adverse events. Budaya tidak saling menyalahkan memungkin individu untuk melaporkan dan mendiskusikan adverse events tanpa khawatir akan dihukum.Aspek lain yang penting penting adalah memastikan memastikan bahwa masingmasing masing-masing individu individu bertanggung bertanggung jawab secara personal dan kolektif terhadap patient safety dan bahwa keselamatan adalah kepentingan semua pihak. 


\section{Daftar Pustaka}

1. Anggraeni, D., \& Azzuhri, M. (2016). Pengaruh budaya keselamatan pasien terhadap sikap melaporkan insiden pada perawat di Instalasi Rawat Inap Rumah Sakit Tk. II dr. Soepraoen. Jurnal aplikasi manajemen, 14(2), 309-321.

2. Anwar, A. W., Kapalawi, I., \& Maidin, M. A. (2014). Hubungan Kepemimpinan Efektif Kepala Ruangan dengan Penerapan Budaya Keselamatan Pasien di Instalasi Rawat Inap RSUD Kota Makassar. Makassar: Universitas Hasanuddin.

3. Dewi, M. (2012). Pengaruh pelatihan timbang terima pasien terhadap penerapan keselamatan pasien oleh perawat pelaksana di RSUD Raden Mattaher Jambi. Jurnal Health and Sport, 5(03).

4. Hartanto, Y. D., \& Warsito, B. E. (2017). Kepemimpinan Kepala Ruang dalam Penerapan Budaya Keselamatan Pasien di Rumah Sakit: Literature Review.

5. Herawati, Y. T. (2015). Budaya keselamatan pasien di ruang rawat inap rumah sakit $X$ Kabupaten Jember. IKESMA, 11(1).

6. Mandriani, E., Hardisman, H., \& Yetti, H. (2019). Analisis Dimensi Budaya Keselamatan Pasien Oleh Petugas Kesehatan di RSUD dr Rasidin Padang Tahun 2018. Jurnal Kesehatan Andalas, 8(1), 131-137.

7. Nivalinda, D., Hartini, M. I., \& Santoso, A. (2013). Pengaruh motivasi perawat dan gaya kepemimpinan kepala ruang terhadap penerapan budaya keselamatan pasien oleh perawat pelaksana pada rumah sakit pemerintah di Semarang. Jurnal Manajemen Keperawatan, 1(2).

8. Rosyada, S. D. (2014). Gambaran Budaya Keselamatan Pasien pada Perawat Unit Rawat Inap Kelas III Rumah Sakit Umum Daerah Pasar ReboBulan Juni Tahun 2014.

9. Simamora, R. H. (2018). Buku ajar keselamatan pasien melalui timbang terima pasien berbasis komunikasi efektif: SBAR. Medan: USUpress.

10. Simamora, R. H. (2020). Learning of Patient Identification in Patient Safety Programs Through Clinical Preceptor Models. Medico Legal Update, 20(3), 553-556.

11. Suci, W. P. (2018). Peningkatan Budaya Keselamatan Pasien melalui Pemberdayaan Champion Keselamatan Pasien. Jurnal Kesehatan Holistic, 2(2), 23-36.

12. Yulia, S., Hamid, A. Y. S., \& Mustikasari, M. (2012). Peningkatan pemahaman perawat pelaksana dalam penerapan keselamatan pasien melalui pelatihan keselamatan pasien. Jurnal Keperawatan Indonesia, 15(3), 185-192. 